\section{Hydrothermal HFSE(+HREE) mineralization in the Bear Lodge Alkaline Complex - a key to understanding the larger Hicks Dome critical mineral resource?}

\author{
ALLEN K. ANDERSEN ${ }^{1}$, ALBERT H. HOFSTRA, PHD ${ }^{1}$ \\ AND LAURENCE M. NUELLE ${ }^{2}$ \\ ${ }^{1}$ U.S. Geological Survey \\ ${ }^{2}$ Hicks Dome LLC \\ Presenting Author: akandersen@usgs.gov
}

Carbonatite critical mineral resources are invariably LREEenriched. Some alkaline-carbonatite complexes also host veins or peripheral zones that are HREE-enriched. For most of these occurrences, HREE mineralization is attributed to LREE-HREE fractionation and late hydrothermal activity. We examine two alkaline-igneous centers in the United States that host similar HFSE(+HREE) mineral assemblages and propose models for their formation.

Hicks Dome is a cryptovolcanic structure that hosts a fluoritebarite resource in the Illinois-Kentucky fluorspar district. In addition to fluorite and barite, Hicks Dome is enriched in HREE and HFSE with an estimated $65.8 \mathrm{Mt}$ area-wide resource averaging $15.8 \%$ fluorite, $4.8 \%$ barite, $1.3 \% \mathrm{TiO}_{2}, 0.3 \% \mathrm{REY}$ oxide, $0.2 \% \mathrm{Nb}_{2} \mathrm{O}_{5}$, and $0.16 \% \mathrm{BeO}$, at a fluorite cut-off grade of $10 \%$. The resource is associated with $271 \mathrm{Ma}$ carbonate-rich, alkaline, lamprophyre dikes and diatremes of the Midwest Permian Ultramafic District. Critical minerals occur in fluoritemineralized rock-flour-matrix breccia and solution-collapse breccia in Ordovician to Silurian platform carbonate rocks at depths of 700-1000 m.

The Eocene Bear Lodge alkaline complex hosts a large REE resource in a weathered, carbonatite dike swarm and vein stockwork. Carbonatites are LREE-enriched with Ca-REE fluorocarbonates as the principal ore minerals. A peripheral HFSE(+HREE) occurrence at Bear Lodge composed of anatase, xenotime-(Y), brockite, fluorite, zircon, and K-feldspar is enriched in a suite of elements similar to the Hicks Dome host breccia (HREE, Th, Ti, Nb, Be, P, F).

We present multielement data from more than 3,000 Hicks Dome drill-core samples, micro-XRF maps of the host breccia, results from mineralogical studies, and compare results with those from the Bear Lodge HFSE(+HREE) occurrence. Despite some major differences between the two critical mineral resources, their geochemistry and unusual mineralogy are remarkably similar. Chondrite-normalized REE profiles for both occurrences have convex patterns from $\mathrm{Sm}$ to $\mathrm{Lu}$ which crossover the associated alkaline igneous rock (carbonatite and lamprophyre) patterns between $\mathrm{Nd}$ and $\mathrm{Eu}$ (figure 1a,b). We discuss a model by which HFSE(+HREE) precipitate from highly fractionated fluids derived from carbonatite or carbonaterich alkalic magmas and the role specific ligands $\left(\mathrm{Cl}, \mathrm{F}, \mathrm{SO}_{4}\right.$, $\mathrm{HCO}_{3}, \mathrm{CO}_{3}$ ) may have in the formation of these resources.
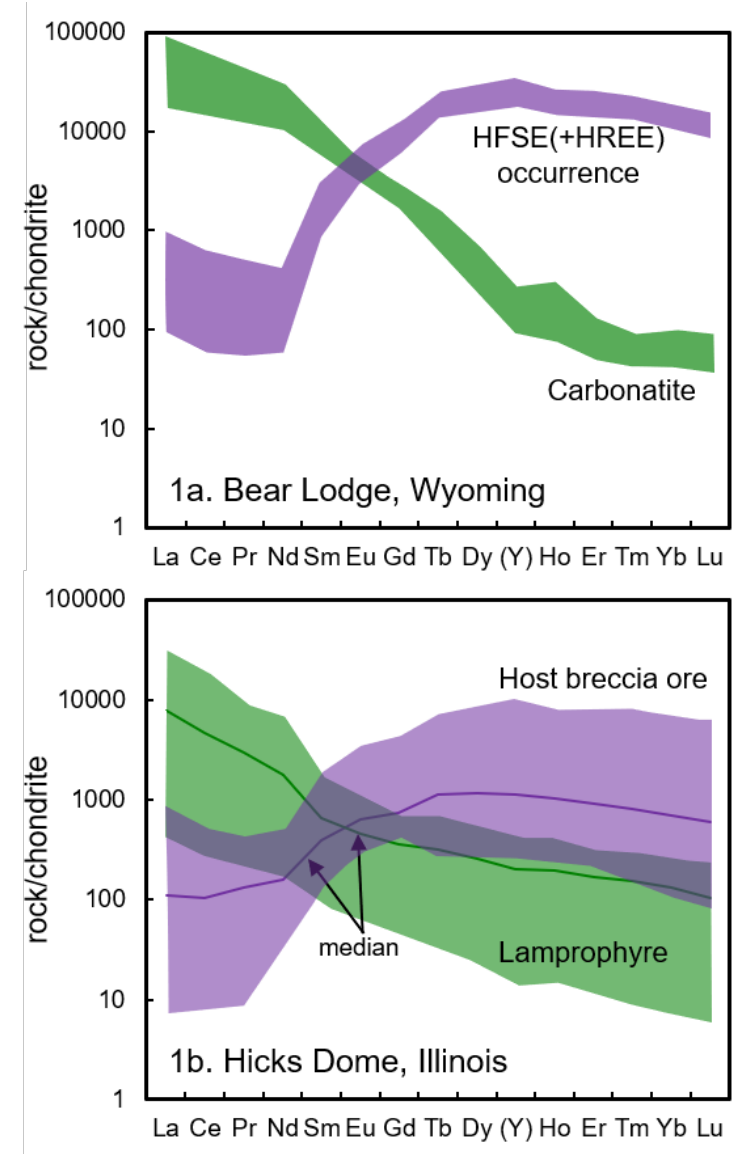